\title{
The Role of ICT in Education: Focus on University Undergraduates taking Mathematics as a Course
}

\author{
Oye, N. D. \\ Department of Information Systems \\ Universiti Teknologi Malaysia
}

\author{
Z.K. Shallsuku, \\ FUTY-Nigeria
}

\author{
A.Iahad, N. \\ Department of Information Systems \\ Universiti Teknologi Malaysia
}

\begin{abstract}
This paper examines the role of ICT in education with focus on university undergraduates taking mathematics as a course. The study was conducted at the Federal University of Technology Yola, Adamawa State, Nigeria. 150 questionnaires were administered to the first year students offering MA112 which was completed and returned in the lecture hall. According to the study ICT usage shows that majority $(32.7 \%)$ use technology once or more in a day. Again the majority of the respondents $(35 \%)$ said that the greatest barrier to using ICT is technical. The survey shows that there is significant correlation between the students and the use of ICT in their studies. However difficulties facing ICT usage is highly significant also. This shows that students have negative attitudes towards using ICT in their academic work. This is a foundational problem which cannot be over emphasized. Most of the students have never practice using ICT in their primary and secondary schools. Recommendations were made, that the government should develop ICT policies and guidelines to support all levels of education from primary schools to university. ICT tools should be made more accessible to both academic staff and students.
\end{abstract}

Keywords- University undergraduates; ICT; Education; ICT tools; ICT infrastructure.

\section{INTRODUCTION}

E-learning is a unifying term used for online learning, webbased training and technology delivered instruction. E-learning is an approach to facilitate and enhance learning both through computer and communication technology. The use of ICT to support teaching and learning within mathematics remains underdeveloped. While there are examples of good practice, there are significant inconsistencies between schools as well as within mathematics departments. Majorities of teachers are still not confident in the use of ICT and requires further training. In some schools and colleges, access to ICT facilities, including graphing calculators, is too limited and an appropriate range of software has not been made available. In other places, where resources are adequate, they are often not used frequently enough or to promote better teaching and learning. Computers are seen to have the potential to make a significant contribution to the teaching and learning of mathematics. In particular, when students are working on computers, it is generally recognized they are more able to focus on patterns, connections between multiple representations, interpretations of representations and so on [1-4]. This sort of computer use may 'enable a deeper, more direct mathematical experience'. In the UK there is a statutory requirement for ICT to be used in mathematics teaching and learning at all levels; the requirements are summarized in statements such as Students should be offered the following opportunities ... using ICT such as spreadsheets, dynamic geometry or graphing software, calculators (DCSF, 2008) In other countries, similar encouragement is given to teachers, and is described by as incentive action and institutional support. However, despite these efforts to embed computers in mathematics teaching and learning, and despite the growing numbers of computers in schools [1], there are some concerns about the degree to which computers have actually become embedded in mathematics classrooms. These concerns fall into three areas: computers are used only marginally in mathematics classes; integration of computers progresses slowly, $[3,5]$ and where computers are used, they are often used by the teachers in whole class teaching rather than by the students. The growth of ICT has drastically reshape the teaching and learning processes in our universities ( $[6,7]$. ICT for education is more critical today than before [8]. The higher education institutions around the globe have increasingly adopted ICT as tools for teaching, cirriculm development, staff development, and student learning $[9,10]$.

According to the [11] much of our curricula and education systems are still products from a mechanistic past, in which predetermined knowledge was delivered in a linear format to a mass audience. The focus was on transferring information in a controlled sequence without accounting for the contextual settings of the different learners. The Universities in Nigeria need to align its teaching and learning methods with best practices found both nationally and globally. Adopting the use of ICT and IS within higher education seems inevitable as digital communication and information models become the preferred means of storing, accessing and disseminating information.

\section{Ease of Use}

\section{ICT IN EDUCATION}

The term, information and communication technologies (ICT), refers to forms of technology that are used to transmit, store, create, share or exchange information. This broad definition of ICT includes such technologies as: radio, television, video, DVD, telephone (both fixed line and mobile phones), satellite systems, computer and network hardware and software; as well as the equipment and services associated with these technologies, such as videoconferencing and electronic 
mail. ICT in education means teaching and learning with ICT. Researches globally have proved that ICT can lead to improve students' learning and better teaching methods. A report made by the National Institute of Multimedia Education in Japan, proved that an increase in student exposure to educational ICT through curriculum integration has a significant and positive impact on student achievement, especially in terms of "Knowledge Comprehension", "Practical skill" and "Presentation skill" in subject areas such as mathematics, science, and social study. While we recognize that the use of instructional technology in the higher education teaching and learning processes is still in its infancy in Nigeria, ICT instructional use is vital to the progress and development of faculty and students alike. Higher education institutions, especially those in the West, have adopted ICT as a means to impart upon students the knowledge and skills demanded by 21 st century educational advancement [9, 10, 12]. ICT also adds value to the processes of learning and to the organization and management of learning institutions. Although some HEIs have the zeal to establish effective ICT education programmes, they are faced with the great problems of proper implementation of the programme. The most important of these is poor ICT penetration and usage among Nigerian higher education practitioners. Almost all African countries' basic ICT infrastructures are inadequate; a result of a lack of electricity to power the ICT materials and poor telecommunication facilities. Above all, this lack of access to infrastructure is the result of insufficient funds[13, 14]. Many cities and rural areas in Nigeria still have fluctuation in their supply of electricity which makes the implementation of ICT in education most difficult. Furthermore most Nigerian universities do not have access to basic instructional technology facilities, which also make the integration of instructional technology in the delivery of quality education difficult. Therefore, computer related telecommunication facilities might not be very useful for most Nigerian students and faculty members, as computers are still very much a luxury in institutions, offices and homes. This has made the integration of essential on-line resources (e-mail, world-wide-web, etc.) into higher education most difficult. In higher education, an important aspect of the shift in technological processes has been to the acceptance and use of ICT for teaching and learning[15]. According to the Commonwealth of Learning International (2001)," another serious challenge facing higher education in Nigeria is the need for integration of new ICT literacy knowledge into academic courses and programs. In this regard, professionals in Nigeria have not been able to benefit from international assistance, international networking and cooperation, or from courses, conferences and seminars abroad, because of lack of funding."

\section{Maintaining the Integrity of the Specifications}

The template is used to format your paper and style the text. All margins, column widths, line spaces, and text fonts are prescribed; please do not alter them. You may note peculiarities. For example, the head margin in this template measures proportionately more than is customary. This measurement and others are deliberate, using specifications that anticipate your paper as one part of the entire proceedings, and not as an independent document. Please do not revise any of the current designations.

\section{Research Questions}

1. Do students use ICT to support their studies?

2. What is the greatest barrier to using ICT by the students?

\section{Methodology}

The research sample are the undergraduate offering MA112 (introduction to calculus) as a major course in the school of pure and applied science FUTY-Nigeria. 150 questionnaires were administered to the first year students which was completed and returned in the lecture hall. In the questionnaire ICT refers to the application of digital equipment to all aspects of teaching and learning which encompasses (PC, TV, Radio, Cellular Phones, Laptop, Overhead Projectors, Slides Projectors, Power-Point Projectors, Electronic Boards, Internet, Hardware, Software, and any technological equipment for teaching and learning). The student is to rate each question based on 1-5 Likert scale, where (1) is Strongly Disagreed and (5) is Strongly Agreed. Descriptive statistics were used to answer the demographic statement. Our statistical results are obtained using SPSS version 17. Using correlation analysis, this paper wants to verify the significant relationship between the undergraduate students and the use of ICT to assist them in their studies.

\section{Summary Of The Demographic StATEMENT}

- The demographic of the survey participants for the gender shows that $(60 \%)$ are male and $(40 \%)$ are female.

- Most of the students are within the age bracket of (1925years) which is $(77.3 \%)$.

- Is ICT mandatory or voluntary at your institution (ICTMV)? The majority of the students (70.7\%) responded that ICT is voluntary. While $24 \%$ of the student responded that ICT is mandatory. This may be due to the fact that most of the first year students have graduated from colleges where ICT in education is not encouraged or ICT facilities are not available.

- The question, how often do you use ICT (HUSEICT)? The summary of the technology usage are as follows: (32.7\%) use technology once or more in a day, (23.3\%) use it once a week, while $(20.7 \%)$ claimed that they have never use technology.

- Most of the respondents are in level 1-2, (89\%). Here we have carry over students they are those that cannot pass the course in their level 1. Again we have some levels: $3(5 \%) ; 4(3 \%)$ and $5(3 \%)$ also repeating the course MA112.

What are the greatest barriers to using ICT to you as an undergraduate? The majority of the respondents (35.3\%) said that their problem is technical; on the other hand $(30 \%)$ said that the problem is cost. Others respondents $(21.3 \%)$ said that training are their problems, another group (9.3\%) said that they need time and the final group $(1.3 \%)$ said that, it does not fit their programme. 
TABLE I. BARRIERS TO USING ICT(BARIERICT)

\begin{tabular}{|c|c|c|c|c|c|}
\hline \multirow{8}{*}{ Valid } & & Frequency & Percent & $\begin{array}{l}\text { Valid } \\
\text { Percent }\end{array}$ & $\underset{\text { Percent }}{\text { Cumulative }}$ \\
\hline & TIME & 14 & 9.3 & 9.3 & 9.3 \\
\hline & TECHNICAL SUPPORT & 53 & 35.3 & 35.3 & 44.7 \\
\hline & COST & 45 & 30.0 & 30.0 & 74.7 \\
\hline & TRAINING & 32 & 21.3 & 21.3 & 96.0 \\
\hline & COMPENSATION & 4 & 2.7 & 2.7 & 98.7 \\
\hline & $\begin{array}{l}\text { DOES NOT FIT } \\
\text { PROGRAM }\end{array}$ & 2 & 1.3 & 1.3 & 100.0 \\
\hline & Total & 150 & 100.0 & 100.0 & \\
\hline
\end{tabular}

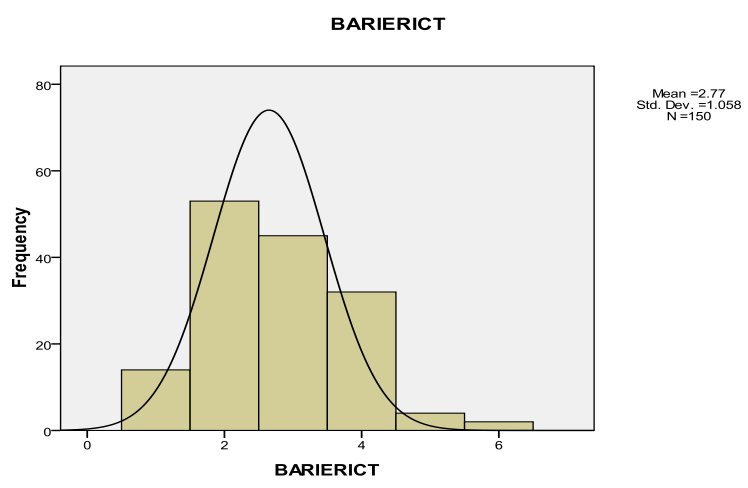

ICT development programme among academic staff of educational institutions especially at the tertiary level is faced by number of obstacles. Prominent among them is the lack of training opportunities for staff. The same problem is recurring in this study again. In a study by[16] lack of interest, limited access to ICT facilities and lack of training opportunities were among the obstacles to ICT usage among academic staff. [17] Opined that inadequate ICT facilities, excess workload and funding were identified as major challenges to ICT usage among academic staff in Nigerian universities. This is affecting the students because they primarily depend on the academic staff.

\section{CORRELATION}

You will find (Tables 2,3, 4, 5, 6, and 7) in appendix A:

- From table2, ICTEDU1 is significant to ICTEDU2, with $\mathrm{r}=33.4$ and the $\mathrm{p}$-value .000 . Correlation result reveals that students' interest to use ICT has significant relation with educational system supporting ICT use in education.

- ICTEDU1 is highly significant to ICTEDU3, with $\mathrm{r}=$ 36.7 and p-value .000 . Here the correlation result reveals that students' interest on the use of ICT has significant relation with the use of ICT in the education system.

- ICTEDU1is highly significant to ICTEDU4, with $\mathrm{r}=$ 37.9 and p-value .000. The correlation result reveals that students' interest to use ICT has significant relation with ICT making education easier for the students.

- ICTEDU3 is also significant to ICTEDU4, with $\mathrm{r}=$ 24.8 and p-value .002 . Correlation result reveals that the use of ICTs in education is significant to ICT making education easier.

- ICTEDU3 is significant to ICTEDU5, with $r=28.4$ and p-value .000.Correlation result reveals that, the use of ICTs in education is significant with promoting education.

- ICTEDU4 is significant to ITCEDU2, with $r=32.0$ and p-value .000.Correlation result reveals that ICT making education easier is significant to ICT promoting education.

- ICTEDU5 is significant ICTEDU2, with $r=16.6$ and p-value .043. Correlation result reveals that ICT promoting education is significant to educational system supporting ICT use in education.

- From table 3, USEICT1 is significant to USEICT2, with $\mathrm{r}=20.4$ and $\mathrm{p}$-value .012 . The correlation result reveals that ICT as a necessary part of education has significant relation with student training on the use of ICT in education.

- USEICT1 is significant to USEICT3, with $r=35.1$ and p-value .000. The correlation result reveals that ICT as a necessary part of education has significant relation with use of ICT in the education system.

- USEICT1 is significant to USEICT4, with $r=26.5$ and p-value .000 . The correlation result reveals that ICT as a necessary part of education has significant relation with ICT making students independent and self learners.

- USEICT2 is significant to USEICT3, with $r=18.7$ and p-value .022. The correlation reveals that students training on ICT have significant relation with ICT assisting students in their work.

- USEICT3 is significant to USEICT4, with $r=20.6$ and $\mathrm{p}=$ value .012. The correlation reveals that ICT assisting students in their work has significant relation with student independent and self-learners.

- $\quad$ From table 4, AICTT1 is significant to AICTT2, with $r=32.4$ and $p$-value .000 . The correlation reveals that use of ICT depends on the available tools and this has significant relation with lack of ICT tools.

- $\quad$ AICTT2 is significant to AICTT3, with $r=16.3$ and $p-$ value .047. The correlation reveals that lack of ICT tools has significant relation with availability of on-line courses.

- AICTT3 is significant to AICTT4, with $r=31.6$ and $p$ value .000 . The correlation reveals that availability of on-line courses has significant relation with availability of ICT tools and facilities. 
- From table 5, ICTA1 is significant to ICTA2 with $r=$ 32.8 and p-value .000 . The correlation result reveals that students' awareness of ICT has significant relation with existing methods to support ICT.

- ICTA3 is significant to ICTA5, with $r=26.1$ and $p$ value .001. The correlation reveals that ICT awareness for teaching and learning has significant relation with importance of using ICT in education.

- ICTA3 is significant to ICTA4, with $r=35.1$ and $p$ value .000. The correlation reveals that ICT awareness for teaching and learning has significant relation with awareness of ICT among students.

- ICTA4 is significant to ICTA5, with $r=19.2$ and $p$ value .018. The correlation reveals that improved awareness of ICT among students has significant relation with institutions using ICTs in education.

- From table 6, DFICTU1 is highly significant to DFICTU2 with $\mathrm{r}=47.6$ and $\mathrm{p}$-value .000 . The correlation result reveals that teachers' factor has significant relation with the lecture hall facilities and size.

- DFICTU1 is significant to DFICT3, with $r=25.7$ and p-value .002. The correlation reveals that teachers factor has significant relation with energy related problem.

- DFICTU1 is significant to DFICTU4, with $r=26.1$ and p-value .001 . The correlation reveals that teachers factor has significant relation with inadequate internet connectivity.

- DFICTU1 is significant to DFICTU5, with $r=27.5$ and p-value .001 . The correlation reveals that teachers factor has significant relation with student knowledge of computer usage.

- DFICTU1 is significant to DFICTU7, with $r=25.1$ and p-value .002.The correlation reveals that teachers factor has significant relation with students' attitudes towards computer.

- DFICTU2 is significant to DFICTU3, with $r=30.7$ and $\mathrm{p}$-value .000 .The correlation shows that lecture hall factor has significant relation with energy related problem and power supply.

- DFICTU2 is significant DFICTU4, with $r=29.8$ and p-value .000. The correlation shows that lecture hall factor has significant relation with inadequate internet connectivity.

- DFICTU2 is significant to DFICTU5, with $r=33.1$ and p-value .000.The correlation shows that lecture hall factor has significant relation with students' knowledge of computer usage.

- DFICTU2 is significant to DFICTU6, with $r=24.9$ and p-value.022. The correlation shows that lecture hall factor has significant relation with the availability of computer.
- DFICTU2 is significant to DFICTU7, with $r=26.0$ and p-value .001. The correlation reveals that lecture hall factor has significant relation with students' attitudes towards computer.

- DFICTU3 is highly significant to DFICTU4, with $r=$ 48.9 and p-value .000 . The correlation reveals that electricity power supply has significant relation with inadequate internet connectivity.

- DFICTU3 is significant to DFICTU5, with $r=36.8$ and p-value .000 . The correlation shows that electricity power supply has significant relation with knowledge of computer usage.

- $\quad$ DFICTU4 is significant to DFICTU5, with $r=45.9$ and p-value .000 . The correlation result reveals that inadequate internet connectivity has significant relation with knowledge of computer usage.

- DFICTU4 is significant to DFICTU6, with $r=42.1$ and $\mathrm{p}$-value .000 . The correlation result shows that inadequate internet connectivity has significant relation with availability of computers.

- DFICTU5 is highly significant toDFICTU6, with $r=$ 46.9 and p-value .000 . The correlation result reveals that Knowledge of computer usage has significant relation with availability of computers.

- DFICTU5 is significant to DFICTU7, with $r=38.3$ and $\mathrm{p}$-value .000 . The correlation shows that knowledge of computer usage has significant relation with students' attitudes towards computer.

- $\quad$ DFICTU6 is significant to DFICTU7, with $r=26.8$ and p-value .001 . The correlation result reveals that availability of computers has significant relation with students' attitudes towards computer.

\section{Discussion}

From table 7, we can summarize that for ICT in Education (ICTEDU), students are interested to use ICTs in education. They believe that ICT will make education easier. Again they believe that the use of ICT will make education system more effective. In the case of (USEICT), the students see ICT as necessary part of education which can assist students in their educational pursue .On the issues of difficulties facing ICT usage (DFICTU). The students consider the energy related problem to be one of the factors affecting inadequate internet connectivity. Hence they believe that if power supply is stable, then internet connectivity will improve. Another problem noted by the student is that most of the teachers are not ICT literate. In addition ICT facilities are not available in the lecture halls, which is crowded with students. The students' attitudes towards computer are negative because most of them do not have the knowledge of computer usage. This is a foundational problem from their primary and secondary school education. In the case of the availability of ICT tools (AICTT), the students state that the use of ICT depends on its' availability therefore, lack of ICT tools affect the use of ICT in education. It is true that the students are aware of ICT (ICTA), however, the 
teaching methods are not supporting the use of ICT because most of the teachers are not ICT literate.

\section{CONCLUSION}

The case of ICT for education and for university undergraduates offering mathematics course in particular are more critical today than ever before since new means of improving instructional methods are triggering a change in the delivery of education. This paper confirms the response of university undergraduate to the role of ICT in education. The summary of the ICT usage shows that majority $(32.7 \%)$ use technology once or more in a day. The majority of the respondents (35\%) said that the greatest barrier to using ICT is technical. The inadequacy of the ICT facilities and infrastructures and lack of opportunities for the university undergraduates for training on how to use ICT for learning and interactions are major problems that must be looked into by the university management. Recommendations were made, that the government should develop ICT policies and guidelines to support both (Primary and Secondary levels), university undergraduates and the academic staff in their academic work. ICT tools should be made more accessible to both academic staff and students.

\section{ACKNOWLEDGEMENT}

The authors would like to acknowledge all the authors of articles sited in this paper. In addition, the authors gratefully acknowledge UTM, Research Universiti Malaysia for their support and encouragement.

\section{Appendix A \\ QUESTIONNAIRE FOR UNIVERSITY STUDENTS}

ICT here refers to the application of digital equipments to all aspects of teaching and learning, which encompasses (PC, TV, Radio, Cellular phones, Laptops, overhead projectors, slide projectors, power-point projector, electronic boards, internet, hardware, software, and any technological equipment for teaching and learning).

Please rate each of the following on 1-5 Likert scale. Where (1) "Strongly Disagree," (2) "Disagree", (3)" Neither Agree nor Disagree", (4) "Agree", and (5) "Strongly Agree".

ICT in Education:

1. Students are interested to use ICTs in Education. -----

2. Our educational system is sufficient to support ICTs to be used in education.

3. By the use of ICTs in education, the education system can be made more effective.

4. ICTs have made education easier-

5. ICTs is invented to promote education

Use of ICTs

1. ICTs is a necessary part of education $-$

2. Student training is essential, apart from using ICTs in education?
3. Can ICTs assist students in education? --

4. ICTs have made students independent and self learners-

5. Most people think that ICTs is limited to computer and internet----------

\section{Difficulties Facing ICTs usage:}

1. Teacher factor------

2. Lecture hall factor-----

3. Energy related problem( Electricity Power supply)----

4. Inadequate internet connectivity-----

5. Knowledge of computer usage--------

6. Availability of computers-------

7. Students' attitude towards computer------

\section{Availability of ICT Tools:}

1. Use of ICTs depends on the available tools-------

2. Lack of ICT tools affects the use of ICTs in education-

3. Availability of on-line courses make education effective-

4. The availability of ICT tools will ensure the development of ICT infrastructure--------

5. Students with computer knowledge facilitate the use of ICTs in education-

\section{ICTs Awareness:}

1. Students are well aware of ICTs

2. Existing methods of teaching are enough to support ICTs- ------

3. ICT in education create awareness for teaching and learning

4. There is still need to improve the awareness of ICTs among students

5. Institutions are trying to create awareness about the importance of using ICTs in education

\section{Demographic Information:}

1. Gender: $1=$ Male $2=$ Female.

2. Age: $1=16-18$ years, $2=19-25$ years, $3=26$ years and above 3. Is ICT use mandatory or voluntary at your institution? $1=$ Mandatory $2=$ Voluntary

4. How often do you use ICT? $1=$ once or more a day, $2=$ once a week,

$3=$ twice a month, $4=$ once a month, $5=$ Never.

5. What is your level? $1=$ Level $[1-2], 2=$ Level $[3$ and above].

6. If you had to pick one issue that is the greatest barrier to using ICT, what would it be?

$1=$ Time, $2=$ Technical support, $3=$ Cost, $4=$ Training, $5=$ Compensation, 
6= Does not fit my program.

\section{REFERENCES}

[1] Condie, R. and B. Munro (2007) The Impact of ICT in schools- a landscape review(Report to Becta). ICT Survey and Research: ICT Resources used in Mathematics. (url: accessed 2007). Volume,

[2] Godwin, S. and R. Surtherland, Whole-class technology for learning mathematics: the case of functions and graphs. Education, Communication and Technology, 2004. 4(1): p. 131-152.

[3] Laborde, C., Integration of Technology in Design of Geometry Tasks with Cabri-Geometry. International Journal of Computers for Mathematical Learning., 2002. 6(3): p. 283-317.

[4] Ruthven, K., S. Hennessy, and S. Brindley, Teacher Representation of the successful use of computerbased tools and resources in secondaryschool English, Mathematics and Science. Teaching and Teacher Education., 2004. 20(3): p. 259-275.

[5] Ruthven, K. and S. Hennessy, A practitioner modelof the use of computer-based tools and resources to support mathematics teaching and learning. Educational Studies in Mathematics., 2002. 49(1): p. 47-88.

[6] Pulkkinen, J., Cultural globalizationand integration of ICT in education, in Educational Technology: Opportunities and Challenges, K.E. Kumpulainen Editor. 2007, Finland: University of Oulu: Oulu. p. 13-23.

[7] Wood, D., Theory, training, and technology: . Education and Training, 1995. 37(1): p. 12-16.

[8] Pajo and C. Wallace, Barriers to the uptake of web-based technology by university teachers. Journal of Distance Education, 2001. 16: p. 70-84.
[9] Kumpulainen, K., ed. Educational technology: Opportunities and challenges. 2007, University of Oulu: Oulu, Finland.

[10] Usluel, Y.K., P. As_kar, and T. Bas_, A structural equation model for ICT usage in higher education. Educational Technology \& Society, 2008. 11: p. 262-273

[11] Carol, K., Linear and Non-linear Learning Blog. 2007.

[12] UNESCO, UNESCO portal on Higher Education Institutions:. 2009, Higher Education Institutions in Nigeria.

[13] Ololube, N.P. and D.E. Egbezor, Educational technology and flexible education in Nigeria: Meeting the need for effective teacher education. in S. Marshal, W. Kinthia and W. Taylor(Eds), Bridging the Knowledge Divide:. Educational technology for edvelopment, 2009: p. 391-413.

[14] Ololube, N.P. and D.E. Egbezor, Educational technology and Flexible education in Nigeria: Meeting the need for effective teacher education. in S. Marshal, W. Kinthia and W. Taylor (Eds), Bridging the Knowledge Divide:. Educational technology for develpoment, 2009: p. 391-413.

[15] Oye, N.D., N. A.Iahad, and N. Ab.Rahim, Adoption and Acceptance of ICT Innovations in Nigerian Public Universities. International Journal of Computer Science Engineering and Technology, 2011. 1(7): p. 434443.

[16] Archibong, I.A. and D.O. Effiom, ICT in University Education: Usage and Challenges among Academic Staff. . Africa Research Review, 2009. 3(2): p. 404-414.

[17] Ijeoma, A.A., E.O. Joseph, and A. Franca, ICT Competence among Academic staff in Unversities in Cross Rivers State, Nigeria. . Computer and Information Science, 2010. 3(4): p. 109-115.

\section{Appendix B}

TABLE II. ICT IN EDUCATION (ICTEDU)

\section{Correlations}

\begin{tabular}{|c|c|c|c|c|c|c|}
\hline & & ICTEDU1 & ICTEDU2 & ICTEDU3 & ICTEDU4 & ICTEDU5 \\
\hline \multirow[t]{3}{*}{ ICTEDU1 } & Pearson Correlation & 1 & $.334 * *$ & $.367 * *$ & $.379 * *$ & .112 \\
\hline & Sig. (2-tailed) & & .000 & .000 & .000 & .172 \\
\hline & $\mathrm{N}$ & 150 & 150 & 150 & 150 & 150 \\
\hline \multirow[t]{3}{*}{ ICTEDU2 } & Pearson Correlation & $.334 * *$ & 1 & .117 & .081 & $.166^{*}$ \\
\hline & Sig. (2-tailed) & .000 & & .153 & .324 & .043 \\
\hline & $\mathrm{N}$ & 150 & 150 & 150 & 150 & 150 \\
\hline \multirow[t]{3}{*}{ ICTEDU3 } & Pearson Correlation & $.367 * *$ & .117 & 1 & $.248 * *$ & $.284 * *$ \\
\hline & Sig. (2-tailed) & .000 & .153 & & .002 & .000 \\
\hline & $\mathrm{N}$ & 150 & 150 & 150 & 150 & 150 \\
\hline \multirow[t]{3}{*}{ ICTEDU4 } & Pearson Correlation & $.379 * *$ & .081 & $.248 * *$ & 1 & $.320 * *$ \\
\hline & Sig. (2-tailed) & .000 & .324 & .002 & & .000 \\
\hline & $\mathrm{N}$ & 150 & 150 & 150 & 150 & 150 \\
\hline \multirow[t]{3}{*}{ ICTEDU5 } & Pearson Correlation & .112 & $.166^{*}$ & $.284 * *$ & $.320 * *$ & 1 \\
\hline & Sig. (2-tailed) & .172 & .043 & .000 & .000 & \\
\hline & $\mathrm{N}$ & 150 & 150 & 150 & 150 & 150 \\
\hline
\end{tabular}

**. Correlation is significant at the 0.01 level (2-tailed).

*. Correlation is significant at the 0.05 level (2-tailed).

TABLE III. USE OF ICT (USEICT)

\section{Correlations}

\begin{tabular}{lllllll}
\hline & USEICT1 & USEICT2 & USEICT3 & \multicolumn{2}{c}{ USEICT4 } & USEICT5 \\
\hline \multirow{2}{*}{ USEICT1 } & Pearson Correlation & 1 & $.204^{*}$ & $.351^{* *}$ & $.265^{* *}$ & .106 \\
& Sig. (2-tailed) & & .012 & .000 & .001 & .195 \\
& $\mathrm{~N}$ & 150 & 150 & 150 & 150 & 150
\end{tabular}




\begin{tabular}{lllllll} 
USEICT2 & Pearson Correlation & $.204^{*}$ & 1 & $.187^{*}$ & .065 & .147 \\
& Sig. (2-tailed) & .012 & & .022 & .427 & .072 \\
& $\mathrm{~N}$ & 150 & 150 & 150 & 150 & 150 \\
USEICT3 & Pearson Correlation & $.351^{* *}$ & $.187^{*}$ & 1 & $.206^{*}$ & .105 \\
& Sig. (2-tailed) & .000 & .022 & & .012 & .199 \\
& $\mathrm{~N}$ & 150 & 150 & 150 & 150 & 150 \\
USEICT4 & Pearson Correlation & $.265^{* *}$ & .065 & $.206^{*}$ & 1 & .119 \\
& Sig. (2-tailed) & .001 & .427 & .012 & & .147 \\
& $\mathrm{~N}$ & 150 & 150 & 150 & 150 & 150 \\
USEICT5 & Pearson Correlation & .106 & .147 & .105 & .119 & 1 \\
& Sig. (2-tailed) & .195 & .072 & .199 & .147 & \\
& $\mathrm{~N}$ & 150 & 150 & 150 & 150 & 150 \\
\hline
\end{tabular}

*. Correlation is significant at the 0.05 level (2-tailed).

**. Correlation is significant at the 0.01 level (2-tailed).

TABLE IV. AVAILABILITY OF ICT TOOLS (AICTT)

Correlations

\begin{tabular}{lllllll}
\hline & & AICTT1 & AICTT2 & AICTT3 & AICTT4 & AICTT5 \\
\hline AICTT1 & Pearson Correlation & 1 & $.324^{* *}$ & .033 & .091 & -.023 \\
& Sig. (2-tailed) & & .000 & .692 & .268 & .784 \\
& $\mathrm{~N}$ & 150 & 150 & 150 & 150 & 150 \\
AICTT2 & Pearson Correlation & $.324 * *$ & 1 & $.163^{*}$ & .150 & .070 \\
& Sig. (2-tailed) & .000 & & .047 & .068 & .397 \\
& $\mathrm{~N}$ & 150 & 150 & 150 & 150 & 150 \\
AICTT3 & Pearson Correlation & .033 & $.163^{*}$ & 1 & $.316^{* *}$ & .121 \\
& Sig. (2-tailed) & .692 & .047 & & .000 & .140 \\
& $\mathrm{~N}$ & 150 & 150 & 150 & 150 & 150 \\
AICTT4 & Pearson Correlation & .091 & .150 & $.316^{* *}$ & 1 & $.292^{* *}$ \\
& Sig. (2-tailed) & .268 & .068 & .000 & & .000 \\
& $\mathrm{~N}$ & 150 & 150 & 150 & 150 & 150 \\
AICTT5 & Pearson Correlation & -.023 & .070 & .121 & $.292^{* *}$ & 1 \\
& Sig. (2-tailed) & .784 & .397 & .140 & .000 & \\
& $\mathrm{~N}$ & 150 & 150 & 150 & 150 & 150 \\
\hline
\end{tabular}

**. Correlation is significant at the 0.01 level (2-tailed).

*. Correlation is significant at the 0.05 level (2-tailed).

TABLE V. ICT AWARENESS (ICTA)

Correlations

\begin{tabular}{lllllll}
\hline & & ICTA1 & ICTA2 & ICTA3 & ICTA4 & ICTA5 \\
\hline ICTA1 & Pearson Correlation & 1 & $.328^{* *}$ & .101 & .006 & .121 \\
& Sig. (2-tailed) & & .000 & .219 & .941 & .141 \\
& $\mathrm{~N}$ & 150 & 150 & 150 & 150 & 150 \\
ICTA2 & Pearson Correlation & $.328^{* *}$ & 1 & .074 & -.110 & .092 \\
& Sig. (2-tailed) & .000 & & .371 & .179 & .263 \\
& $\mathrm{~N}$ & 150 & 150 & 150 & 150 & 150 \\
ICTA3 & Pearson Correlation & .101 & .074 & 1 & $.351^{* *}$ & $.261^{* *}$ \\
& Sig. (2-tailed) & .219 & .371 & & .000 & .001 \\
& $\mathrm{~N}$ & 150 & 150 & 150 & 150 & 150 \\
ICTA4 & Pearson Correlation & .006 & -.110 & $.351^{* *}$ & 1 & $.192^{*}$ \\
& Sig. (2-tailed) & .941 & .179 & .000 & & .018
\end{tabular}




\begin{tabular}{lllllll} 
& $\mathrm{N}$ & 150 & 150 & 150 & 150 & 150 \\
ICTA5 & Pearson Correlation & .121 & .092 & $.261^{* *}$ & $.192^{*}$ & 1 \\
& Sig. (2-tailed) & .141 & .263 & .001 & .018 & \\
& $\mathrm{~N}$ & 150 & 150 & 150 & 150 & 150 \\
\hline
\end{tabular}

**. Correlation is significant at the 0.01 level (2-tailed).

*. Correlation is significant at the 0.05 level (2-tailed).

TABLE VI. DIFFICULTIES FACING ICt UsAge (DFICTU):

\section{Correlations}

\begin{tabular}{|c|c|c|c|c|c|c|c|c|}
\hline & & DFICTU1 & DFICTU2 & DFICTU3 & DFICTU4 & DFICTU5 & DFICTU6 & DFICTU7 \\
\hline \multirow[t]{3}{*}{ DFICTU1 } & Pearson Correlation & 1 & & & & & & \\
\hline & Sig. (2-tailed) & & & & & & & \\
\hline & $\mathrm{N}$ & 150 & & & & & & \\
\hline \multirow[t]{3}{*}{ DFICTU2 } & Pearson Correlation & $.476^{* *}$ & 1 & & & & & \\
\hline & Sig. (2-tailed) & .000 & & & & & & \\
\hline & $\mathrm{N}$ & 150 & 150 & & & & & \\
\hline \multirow[t]{3}{*}{ DFICTU3 } & Pearson Correlation & $.257 * *$ & $.307 * *$ & 1 & & & & \\
\hline & Sig. (2-tailed) & .002 & .000 & & & & & \\
\hline & $\mathrm{N}$ & 150 & 150 & 150 & & & & \\
\hline \multirow[t]{3}{*}{ DFICTU4 } & Pearson Correlation & $.261 * *$ & $.298^{* * *}$ & $.489^{* *}$ & 1 & & & \\
\hline & Sig. (2-tailed) & .001 & .000 & .000 & & & & \\
\hline & $\mathrm{N}$ & 150 & 150 & 150 & 150 & & & \\
\hline \multirow[t]{3}{*}{ DFICTU5 } & Pearson Correlation & $.275^{* *}$ & $.331 * *$ & $.368 * *$ & $.459^{* *}$ & 1 & & \\
\hline & Sig. (2-tailed) & .001 & .000 & .000 & .000 & & & \\
\hline & $\mathrm{N}$ & 150 & 150 & 150 & 150 & 150 & & \\
\hline \multirow[t]{3}{*}{ DFICTU6 } & Pearson Correlation & .140 & $.249^{* *}$ & $.307 * *$ & $.421 * *$ & $.469 * *$ & 1 & \\
\hline & Sig. (2-tailed) & .088 & .002 & .000 & .000 & .000 & & \\
\hline & $\mathrm{N}$ & 150 & 150 & 150 & 150 & 150 & 150 & \\
\hline \multirow[t]{3}{*}{ DFICTU7 } & Pearson Correlation & $.251^{* *}$ & $.260 * *$ & .149 & .132 & $.388^{* *}$ & $.268^{* *}$ & 1 \\
\hline & Sig. (2-tailed) & .002 & .001 & .068 & .107 & .000 & .001 & \\
\hline & $\mathrm{N}$ & 150 & 150 & 150 & 150 & 150 & 150 & 150 \\
\hline
\end{tabular}

**. Correlation is significant at the 0.01 level (2-tailed).

TABLE VII. SUMMARY Of THE CORRELATION

\begin{tabular}{ccc}
\hline Significant & R & P-values \\
\hline ICTEDU1 to ICTEDU2 & 33.4 & .000 \\
ICTEDU1 to ICTEDU3 & 36.7 & .000 \\
ICTEDU1 to ICTEDU4 & 37.9 & .000 \\
ICTEDU4 to ICTEDU5 & 32.0 & .000 \\
USEICT1 to USEICT3 & 35.1 & .000 \\
USEICT1 to USEICT4 & 26.5 & .001 \\
DFICTU1 to DFICTU2 & 47.6 & .000 \\
DFICTU2 to DFICTU5 & 33.1 & .000 \\
DFICTU3 to DFICTU4 & 48.9 & .000 \\
DFICTU3 to DFICTU5 & 36.8 & .000 \\
DFICTU4 to DFICTU5 & 45.9 & .000 \\
DFICTU4 to DFICTU6 & 42.1 & .000 \\
DFICTU5 to DFICTU6 & 46.9 & .000 \\
DFICTU5 to DFICTU7 & 38.8 & .000 \\
AICTT1 to AICTT2 & 32.4 & .000 \\
AICTT3 to AICTT4 & 31.6 & .000 \\
ICTA1 to ICTA2 & 32.8 & .000 \\
ICTA3 to ICTA4 & 35.1 & .000 \\
\hline
\end{tabular}

